\title{
CDK12 Gene Mutation
}

National Cancer Institute

\section{Source}

National Cancer Institute. CDK12 Gene Mutation. NCI Thesaurus. Code C131796.

A change in the nucleotide sequence of the CDK12 gene. 